\title{
High-frequency oscillatory ventilation is not superior to conventional mechanical ventilation in surfactant-treated rabbits with lung injury
}

\author{
D. Gommers ${ }^{+}$, A. Hartog ${ }^{+}$, R. Schnabel ${ }^{\#}$, A. De Jaegere*, B. Lachmann ${ }^{+}$
}

\begin{abstract}
High-frequency oscillatory ventilation is not superior to conventional mechanical ventilation in surfactant-treated rabbits with lung injury. D. Gommer, A. Hartog, R. Schnabel, A. De Jaegere, B. Lachmann. (C)ERS Journals Ltd 1999.

ABSTRACT: The aim of this study was to compare high-frequency oscillatory ventilation (HFOV) with conventional mechanical ventilation (CMV) with and without surfactant in the treatment of surfactant-deficient rabbits. A previously described saline lung lavage model of lung injury in adult rabbits was used. The efficacy of each therapy was assessed by evaluating gas exchange, lung deflation stability and lung histopathology.

Arterial oxygenation did not improve in the CMV group without surfactant but increased rapidly to prelavage values in the other three study groups. During deflation stability, arterial oxygenation decreased to postlavage values in the group that received HFOV alone, but not in both surfactant-treated groups (HFOV and CMV). The HFOV group without surfactant showed more cellular infiltration and epithelial damage compared with both surfactant-treated groups. There was no difference in gas exchange, lung deflation stability and lung injury between HFOV and CMV after surfactant therapy.

It is concluded that the use of surfactant therapy in combination with highfrequency oscillatory ventilation is not superior to conventional mechanical ventilation in improving gas exchange, lung deflation stability and in the prevention of lung injury, if lungs are kept expanded. This indicates that achieving and maintaining alveolar expansion (i.e. open lung) is of more importance than the type of ventilator. Eur Respir J 1999; 14: 738-744.
\end{abstract}

Depts of Anaesthesiology, Erasmus University Rotterdam, the Netherlands; "Pathology, Ruhr University Bochum, Germany; and *Pediatrics, Sophia Children's Hospital, Rotterdam, the Netherlands.

\section{Correspondence: D. Gommers}

Dept. of Anaesthesiology (Room Ee 2393)

Erasmus University

Rotterdam PO Box 1738

3000 DR Rotterdam

the Netherlands

Fax: 31104089450

\section{Keywords: Animal}

CMV

HFOV

pulmonary surfactants

rabbit

respiratory distress

ventilator induced lung injury

Received: November 31998

Accepted after revision July 211999
In the first reported high-frequency oscillatory ventilation (HFOV) trial, a low distending airway pressure was used in order to minimize the risk of barotrauma [1]. However, experimental studies have shown that alveoli should be actively opened and that a relatively high airway pressure has to be used to stay above the closing pressure to avoid hypoxaemia and lung injury [2, 3]. Results of recent pilot studies in neonates with respiratory distress syndrome (RDS) applying this high-lung volume strategy are encouraging [4-6].

To date, very few studies have been published on the combined use of surfactant and HFOV in animals or humans [4, 6-9]. Those studies demonstrated that after surfactant therapy HFOV was superior to conventional mechanical ventilation (CMV) in improving pulmonary function and reducing lung injury [4, 6-9]. However, in those studies, HFOV was used in combination with the high-lung volume strategy whereas CMV was not. Recently, FrOESE et al. [8] compared HFOV to CMV after surfactant therapy at low- and high-lung volume and confirmed that HFOV at high-lung volume was superior to the alternatives in

For editorial comments see page 733. improving gas exchange and lung mechanics in lunglavaged rabbits. Surprisingly, these authors were not able to maintain oxygenation above $46.7 \mathrm{kPa}(350 \mathrm{mmHg})$, despite the high-lung volume strategy, after surfactant therapy with the use of CMV [8]. This finding is in contrast to earlier results of CMV with surfactant therapy in lung-lavaged rabbits in which oxygenation increased rapidly to prelavage values after surfactant instillation and was kept stable for hours [10-12]. The purpose of the present study was to compare the use of HFOV to CMV with and without surfactant therapy in the management of acute lung injury caused by lung lavage in adult rabbits.

\section{Methods}

\section{Animal preparation}

This study was approved by the local Animal Committee of the Erasmus University Rotterdam; care and handling of the animals were in accord with the European Community guidelines (86/609/EEG) [13]. A total of 27 adult New Zealand White rabbits (IFFA-Credo, Brussels, 
Belgium) with a mean body weight of $2.7 \pm 0.3 \mathrm{~kg}$ were anaesthetized with pentobarbital sodium $\left(50 \mathrm{mg} \cdot \mathrm{kg}^{-1}\right)$ via an auricular vein and then placed in a supine position. An endotracheal tube (i.d. $3.5 \mathrm{~mm}$ ) was inserted via tracheostomy and mechanical ventilation was initiated with a Servo Ventilator 900C (Siemens-Elema AB, Solna, Sweden) in a pressure-control mode, indicating time-cycled ventilation with decelerating flow, with the following ventilator settings: inspiratory oxygen fraction $\left(\mathrm{FI}, \mathrm{O}_{2}\right)$ of 1.0 , positive end-expiratory pressure (PEEP) of $2 \mathrm{cmH}_{2} \mathrm{O}$, frequency of 30 breaths $\cdot \mathrm{min}^{-1}$, inspiratory/expiratory ratio of 1:2 and a peak inspiratory pressure of $10-14 \mathrm{cmH}_{2} \mathrm{O}$ to keep carbon dioxide tension in arterial blood $\left(\mathrm{Pa}_{\mathrm{a}}, \mathrm{CO}_{2}\right)$ within normal range. An infusion of $2.5 \%$ glucose was continuously administered via the auricular vein as a maintenance fluid $\left(5 \mathrm{~mL} \cdot \mathrm{kg}\right.$ body weight $\left.{ }^{-1} \cdot \mathrm{h}^{-1}\right)$. Anaesthesia was maintained by hourly injection of pentobarbital sodium $\left(5 \mathrm{mg} \cdot \mathrm{kg}\right.$ body weight ${ }^{-1} \cdot \mathrm{h}^{-1}, i . v$. $)$; muscle paralysis was achieved by hourly injection of pancuronium bromide $\left(0.1 \mathrm{mg} \cdot \mathrm{kg}\right.$ body weight ${ }^{-1} \cdot \mathrm{h}^{-1}$, i.m. $)$.

A carotid artery was cannulated for continuous blood pressure measurements and for intermittent blood sampling. Arterial samples were analysed for blood gases, $\mathrm{pH}$ and haemoglobin using conventional methods (ABL-505 and Osm-3; Radiometer, Copenhagen, Denmark). Core temperature was monitored with an oesophageal thermistor (Elektrolaboratoriet, Copenhagen, Denmark) and maintained within normal range by a heating pad.

\section{Induction of lung injury}

In all animals, respiratory insufficiency was induced by repeated whole-lung lavage according to the technique described by LACHMANN et al. [14]. Each lavage was performed with saline $\left(30 \mathrm{~mL} \cdot \mathrm{kg}\right.$ body weight $\left.{ }^{-1}\right)$ heated to $37^{\circ} \mathrm{C}$. Lung lavage was repeated 5-8 times at 2-5 min intervals to achieve a $\mathrm{Pa}, \mathrm{O}_{2}<11.3 \mathrm{kPa}(<85 \mathrm{mmHg})$ at a peak pressure of $26 \mathrm{cmH}_{2} \mathrm{O}$ and a PEEP of $6 \mathrm{cmH}_{2} \mathrm{O}$ (other ventilator settings were not changed).

\section{Study design}

After reaching steady state, 24 animals were divided randomly into four groups of 6 animals. In the first group, animals received a bolus $\left(100 \mathrm{mg} \cdot \mathrm{kg}\right.$ body weight ${ }^{-1}, 25$ $\mathrm{mg} \cdot \mathrm{mL}^{-1}$ ) of a natural surfactant intratracheally (Alveofact ${ }^{\mathbb{R}}$; Thomae, Biberach, Germany) and immediately followed by connection to a high-frequency oscillator (type OHF-1; S.A. Dufour, Villeneuve d'Ascq, France). During HFOV, a frequency of $10 \mathrm{~Hz}$ was used and mean airway pressure (MAwP) was increased until $\mathrm{Pa}, \mathrm{O}_{2}$ was above $46.7 \mathrm{kPa}(350 \mathrm{mmHg})$ to guarantee the high-lung volume strategy (i.e. open lungs) $[4,5]$. When $\mathrm{Pa}_{\mathrm{a}} \mathrm{O}_{2}$ was above $73.3 \mathrm{kPa}(550 \mathrm{mmHg})$ during the study period, MAwP was decreased by steps of $1 \mathrm{cmH}_{2} \mathrm{O}$. Pressure amplitude was initiated with $30 \mathrm{cmH}_{2} \mathrm{O}$ and was altered as necessary to maintain $P \mathrm{a}, \mathrm{CO}_{2}$ within the normal range (4.7-6.0 $\mathrm{kPa}(35-45 \mathrm{mmHg})$ ). The second group received exogenous surfactant intratracheally (Alveofact ${ }^{\mathrm{R}} ; 100$ $\mathrm{mg} \cdot \mathrm{kg}$ body weight ${ }^{-1}$ ) and CMV with the Servo Ventilator 900C (Siemens-Elena AB) was continued (ventilator settings were not changed). For instillation of surfactant, the animals were disconnected from the ventilator and received the surfactant suspension $\left(25 \mathrm{mg} \cdot \mathrm{mL}^{-1}\right)$ directly into the endotracheal tube via a syringe followed by immediate reconnection to the ventilator. The other two groups served as controls and received HFOV or CMV alone in the same manner as described above.

After $4 \mathrm{~h}$ of ventilation, MAwP was first decreased to 12 $\mathrm{cmH}_{2} \mathrm{O}$ for $10 \mathrm{~min}$ in those animals with a MAwP of $\geq 12$ $\mathrm{cmH}_{2} \mathrm{O}$ and then to 9 and $6 \mathrm{cmH}_{2} \mathrm{O}$ during the same period of time. To get a MAwP of $9 \mathrm{cmH}_{2} \mathrm{O}$ in the CMV groups, Peak inspiratory pressure (PIP) was reduced from 26 to 21 $\mathrm{cmH}_{2} \mathrm{O}$ and PEEP was reduced from 6 to $4 \mathrm{cmH}_{2} \mathrm{O}$. Thereafter, PIP was reduced from 21 to $16 \mathrm{cmH}_{2} \mathrm{O}$ and PEEP was reduced from 4 to $2 \mathrm{cmH}_{2} \mathrm{O}$ in order to get a MAwP of $6 \mathrm{cmH}_{2} \mathrm{O}$. Finally, all study groups were restarted on $\mathrm{CMV}$ at the same settings as they were during lung lavage $\left(\mathrm{PIP} / \mathrm{PEEP}=26 / 6 \mathrm{cmH}_{2} \mathrm{O}\right)$. Ten minutes later, blood samples were taken for blood gases.

During the observation period ( $4 \mathrm{~h}$ and $40 \mathrm{~min}$ ), arterial blood samples were collected at the following times: before lavage; 5 and $10 \mathrm{~min}$ after the last lavage; 5, 15, 30 min after surfactant or HFOV application; every $30 \mathrm{~min}$ for $4 \mathrm{~h} ; 10 \mathrm{~min}$ after the three reduction steps of MAwP; and finally 10 min after CMV with the same settings as during the lavage procedure. Continuous blood pressure monitoring enabled observation of changes of mean arterial blood pressure. Volume expansion (Isodex ${ }^{\circledR} ; 5 \mathrm{~mL} \cdot \mathrm{kg}$ body weight $^{-1}$, i.v.) was indicated when mean arterial pressure was below $6.7 \mathrm{kPa}(50 \mathrm{mmHg})$.

\section{Pathological evaluations}

At the end of the observation period, lungs were ventilated with air with no changes in the ventilatory parameters. The abdomen of the rabbit was opened and the diaphragm was inspected for evidence of pneumothorax. The inferior vena cave was cannulated and perfused with a solution, consisting of saline saturated with $95 \% \mathrm{O}_{2}$ and $5 \% \mathrm{CO}_{2}, 2.2$ $\mathrm{mM} \mathrm{CaCl} 2,0.5 \%$ procaine and $1 \%$ heparin, at a rate of 50 $\mathrm{mL} \cdot \mathrm{min}^{-1}$. The abdominal aorta was cut and the infusion was stopped when clear fluid flowed from the aorta. Thereafter, the peak pressure was lowered to $1 \mathrm{cmH}_{2} \mathrm{O}$, and maintained while the lungs were fixated by infusing $\sim 100 \mathrm{~mL}$ of a fixation solution, consisting of $3.6 \%$ formaldehyde and $0.25 \%$ glutaraldehyde, via the inferior vena cave. After fixation, the trachea was clamped at a pressure of $6 \mathrm{cmH}_{2} \mathrm{O}$, the thorax was opened and the lungs were removed en bloc and stored in the fixation solution. The lungs were numbered and histopathological examinations of the lungs were performed blindly. The lungs of the three remaining animals were fixed $10 \mathrm{~min}$ after the lavage procedure as described above. These animals were used to study the influence of the lavage procedure itself on morphological changes.

The lungs were then embedded in paraffin, sectioned and stained with the haematoxylin and eosin (HE) and elastica-van Gieson (EvG) technique. A semi-quantitative morphometric analysis of lung injury was performed under blinded conditions by a pathologist who scored atelectasis, oedema, vascular wall thickening and leukocyte infiltration as none, light, moderate or severe (score $0-3$ ). Lung injury score was defined as the average from all parameters for each group. For transmission electron microscopic examination, lung tissue was precontrasted with $2 \%$ osmium 
acid, dehydrated, and embedded in epoxy resin (Epon $812)$. Semi-thin sections $(1.5 \mu \mathrm{m})$ and ultrathin sections $(0.5 \mu \mathrm{m})$ were produced. Semi-thin sections were stained with $2 \%$ methylene blue and $3 \%$ alkaline fuchsin. Ultrathin sections were counterstained with uranyl acetate and lead citrate. The specimens for the scanning electron microscope were dehydrated with increasing lines of alcoholic solutions, dried with the critical point method, and sputtered with gold.

\section{Statistical analysis}

All data are expressed as mean \pm SD. Analysis of variance (ANOVA) was used to assess whether there was an overall difference within or between the two groups. If a difference was found, a post hoc test was used (Student-NewmanKeuls' multiple comparison procedure). Lung injury data were analysed using the Kurskal-Wallis nonparametric ANOVA test, followed by Dunn's multiple comparisons test if a difference was found. Statistical significance was accepted at p-values 0.05 .

\section{Results}

Blood gases before lavage and directly after lavage were comparable in all animals. In one animal of the HFOV group which developed a pneumothorax at $210 \mathrm{~min}$ of ventilation, measurements were discontinued but the lungs were fixed for histological examinations.

Mean $\mathrm{Pa}_{\mathrm{a}} \mathrm{O}_{2}$ values in both $\mathrm{HFOV}$ groups (with or without surfactant) were kept above $46.7 \mathrm{kPa}(350 \mathrm{mmHg})$ in the first $4 \mathrm{~h}$ by using appropriate MAwP (fig. 1, table 1). In the CMV group with surfactant, $P \mathrm{a}, \mathrm{O}_{2}$ increased from $8.3 \pm 2.1 \mathrm{kPa}(62 \pm 16 \mathrm{mmHg})$ to $53.3 \pm 10.7 \mathrm{kPa}(400 \pm 80$ $\mathrm{mmHg}$ ) within $5 \mathrm{~min}$ and remained stable during the subsequent $4 \mathrm{~h}$ without changing the ventilator settings (fig. 1). In the CMV group without surfactant, mean $\mathrm{Pa}, \mathrm{O}_{2}$ values gradually decreased over time and all animals died after reduction of the MAwP to $9 \mathrm{cmH}_{2} \mathrm{O}$ (fig. 1). Mean $\mathrm{Pa}_{\mathrm{a}} \mathrm{O}_{2}$ values were comparable up to a MAwP of 12 $\mathrm{cmH}_{2} \mathrm{O}$ between the following groups: HFOV without surfactant; HFOV with surfactant; and CMV with surfactant (fig. 1). Mean $P \mathrm{a}, \mathrm{O}_{2}$ values of the animals ventilated with HFOV without surfactant dropped to post-lavage values after MAwP was lowered to 9 and $6 \mathrm{cmH}_{2} \mathrm{O}$, respectively. Mean $\mathrm{Pa}, \mathrm{O}_{2}$ values did not improve when those HFOV animals were switched to CMV at the end of the observation period. However, in both surfactant-treated groups (HFOV and CMV) mean $\mathrm{Pa}_{\mathrm{a}} \mathrm{O}_{2}$ values were significantly higher at a MAwP of 9 and $6 \mathrm{cmH}_{2} \mathrm{O}$ compared to the group $\mathrm{HFOV}$ without surfactant (fig. 1). Furthermore, mean $\mathrm{Pa}, \mathrm{O}_{2}$ values restored to the $\mathrm{Pa}, \mathrm{O}_{2}$ levels at time point $4 \mathrm{~h}$ in both surfactant-treated groups (HFOV and CMV) after CMV for 10 min with the same settings as used during the lavage procedure, indicating a MAwP of $\pm 12 \mathrm{cmH}_{2} \mathrm{O}$ (fig. 1).

The mean carbon dioxide tension in arterial blood $\left(P \mathrm{a}, \mathrm{CO}_{2}\right)$ values gradually increased in the group treated with CMV without surfactant (table 2). In the other three groups, mean $\mathrm{Pa}_{\mathrm{a}} \mathrm{CO}_{2}$ values were maintained at 4.7-6.0 $\mathrm{kPa}(35-45 \mathrm{mmHg})$. MAwP data are shown in table 2. In both groups that received HFOV (with or without

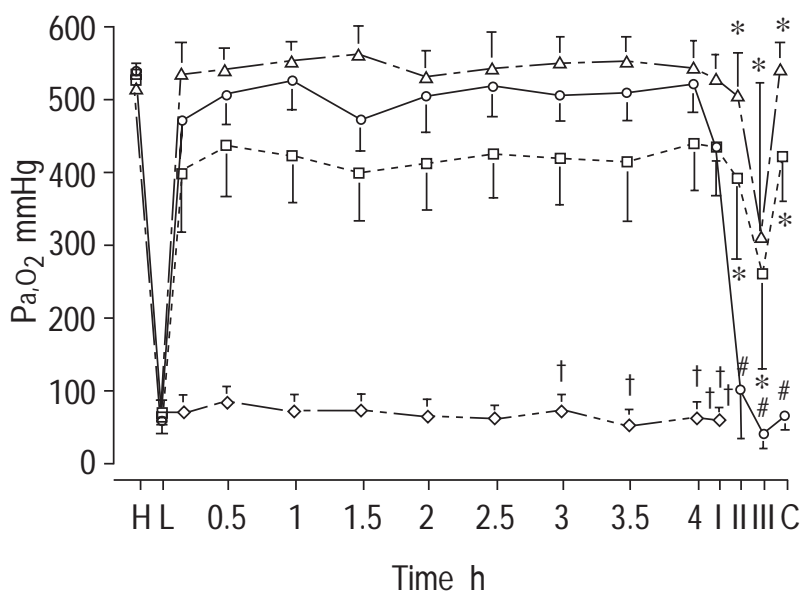

Fig. 1 - Change in mean arterial oxygen tension $\left(\mathrm{Pa}_{\mathrm{a}} \mathrm{O}_{2}\right)( \pm \mathrm{SD})$ of the four study groups before lung lavage $(\mathrm{H}$; healthy), after lavage $(\mathrm{L} ; 10$ min after the last lavage), and during the subsequent $4 \mathrm{~h}$ and $40 \mathrm{~min}$ observation period. I, II and III are the three reduction steps of mean airway pressure (MAwP) to: $\mathrm{I}=12 \mathrm{cmH}_{2} \mathrm{O}$; II=9 $\mathrm{cmH}_{2} \mathrm{O}$; III=6 $\mathrm{cmH}_{2} \mathrm{O}$. $\mathrm{C}$ is the group with conventional mechanical ventilation (CMV) with the same settings as during the lavage procedure, indicating a MAwP of \pm 12 $\mathrm{cmH}_{2} \mathrm{O}$. $\mathrm{O}$ : animals $(\mathrm{n}=6)$ that received high-frequency oscillatory ventilation (HFOV) without surfactant; $\diamond$ : animals $(n=6)$ that received CMV without surfactant; $\square$ : animals $(\mathrm{n}=6)$ that received CMV and surfactant $\left(100 \mathrm{mg} \cdot \mathrm{kg}\right.$ body weight $\left.{ }^{-1}\right) ; \triangle$ : animals $(\mathrm{n}=6)$ that received HFOV and surfactant $\left(100 \mathrm{mg} \cdot \mathrm{kg}\right.$ body weight $\left.{ }^{-1}\right)$. *: p0.05 versus HFOV group; ${ }^{\#}$ : $\mathrm{p} \leq 0.05$ versus $\mathrm{Pa}, \mathrm{O}_{2}$ values at $4 \mathrm{~h}$; ${ }^{\dagger}$ : death of one animal. 1 $\mathrm{mmHg}=0.133 \mathrm{kPa}$.

surfactant), MAwP was initially increased to 18-20 $\mathrm{cmH}_{2} \mathrm{O}$ and could be decreased significantly during the subsequent $4 \mathrm{~h}$ while $\mathrm{Pa}_{\mathrm{a}} \mathrm{O}_{2}$ remained stable. At $4 \mathrm{~h}$, MAwP in the HFOV group with surfactant was significantly lower compared to the HFOV group without surfactant (table 1).

All animals showed evidence of pneumonitis that was composed mainly of eosinophils with some neutrophils. The three animals that were lavaged only and ventilated with CMV for $10 \mathrm{~min}$ also showed a pneumonitis that was similar in extent and distribution as in the animals in the four study groups. The pneumonitis was similar to that originally described by LACHMANN et al. [14] and the presence of the pneumonitis even in the lavage control animals suggested that a chemical pneumonitis is induced by the lavage process itself [2]

Figure 2 shows the lung injury score of the different groups. Animals treated with surfactant combined with HFOV or CMV had significantly less lung injury than animals without surfactant (HFOV and CMV) at the end of the ventilation period. The extent of lung injury of both surfactant-treated groups was comparable with that of the animals that were lavaged only. Representative photomicrographs of the lungs are shown in figures 3 and 4 . More detailed quantitative comparisons between both surfactant treated groups (HFOV and CMV) were not made.

\section{Discussion}

In the present study the lung lavage model that has proved to be a consistent and convenient model of acute lung injury was used $[10-12,14]$. Despite the use of adult 


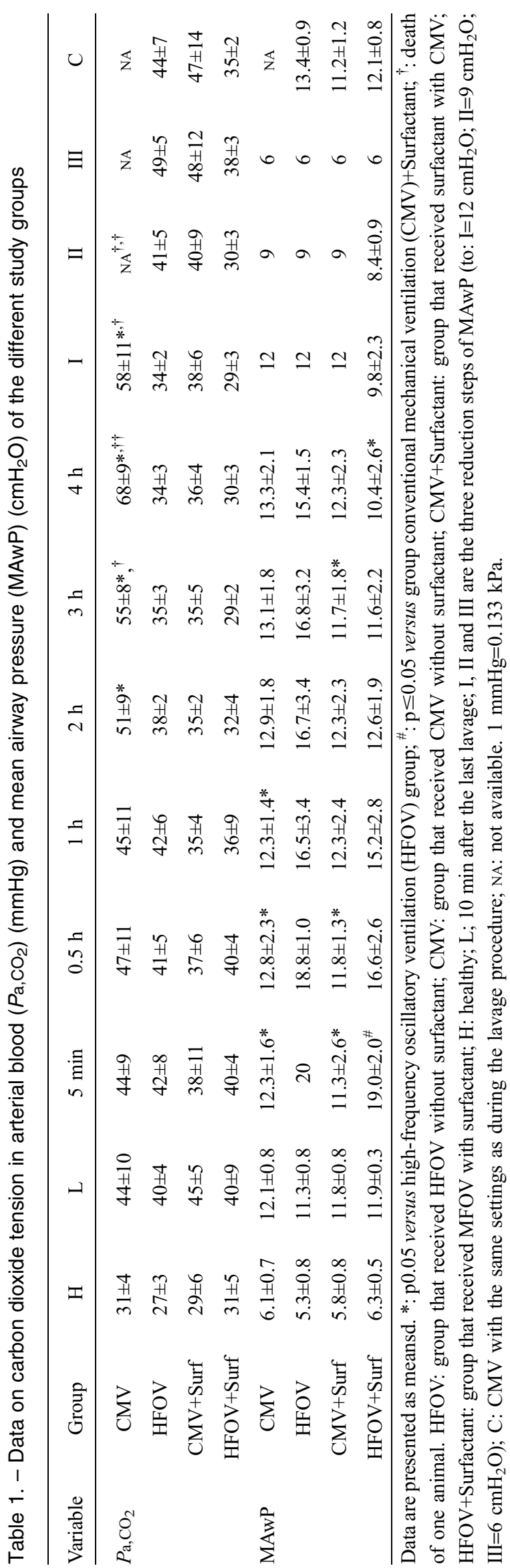

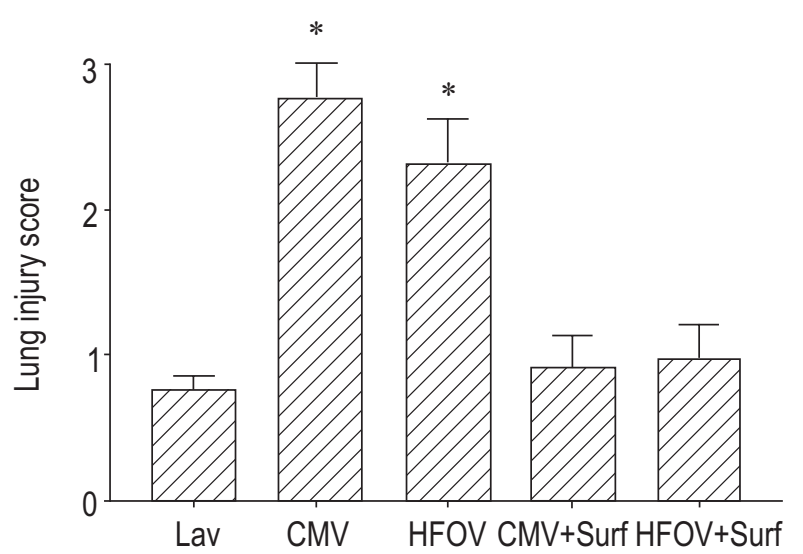

Fig. 2 - Semi-quantitative lung injury score for all groups. Lav: animals that were lavaged only; CMV: conventional machanical ventilation; HFOV: high-frequency oscillatory ventilation; CMV+Surf: animals that received CMV and surfactant; HFOV+Surf: animals that received HFOV and surfactant. *: $\mathrm{p} \leq 0.05$ versus animals that were lavaged only. Data are presented as mean \pm SD.

animals, it has been postulated that this model reflects a primary surfactant deficiency, as seen in neonatal RDS [15]. Several investigators have confirmed the direct relationship in this model between arterial oxygenation and lung volume $[2,3,11,16]$. It has been demonstrated that arterial oxygenation increased with increasing lung volume as alveoli re-expanded and shunt flow decreased [16]. In the present study, arterial oxygenation was therefore used as a reflection of lung volume.

The results of this study demonstrate that after surfactant therapy there is no difference between the use of HFOV and CMV in improving gas exchange, lung deflation stability and prevention of lung injury in lung-lavaged rabbits. These results are in contrast to the results of FROESE et al. [8] who demonstrated that the effect of exogenous surfactant on arterial oxygenation remained stable with HFOV, whereas it decreased significantly during the $4 \mathrm{~h}$ study period with CMV at high-lung volume. In their study, the high-lung volume strategy with CMV was performed by a gradual increase of PIP and PEEP but without an active volume recruitment manoeuvre as used with HFOV [8]. Furthermore, CMV was used with high tidal volumes $\left(20 \mathrm{~mL} \cdot \mathrm{kg}\right.$ body weight $\left.{ }^{-1}\right)$ which is known to increase the conversion from active into nonactive surfactant subfractions; this leads to a shortage of "active" surfactant at alveolar level $[17,18]$. In the present study, an active volume recruitment manoeuvre was not performed with CMV after surfactant therapy, but arterial oxygenation increased to above $46.7 \mathrm{kPa}(350 \mathrm{mmHg})$ within 5 min (without change of ventilator settings) and kept stable during the subsequent $4 \mathrm{~h}$. In contrast to the study of FroEse et al. [8], this study utilized normal tidal volumes $\left(10 \mathrm{~mL} \cdot \mathrm{kg}\right.$ body weight $\left.{ }^{-1}\right)$ and installed the surfactant at a higher concentration (100 $\mathrm{mg} \cdot \mathrm{kg}$ body weight $\left.{ }^{-1}\right)$ and as one bolus, that is known to improve the surfactant distribution and its efficacy [12].

Surfactant metabolism and turnover is known to be strongly influenced by ventilation and some authors suggested that secretion of surfactant is increased with HFOV [19-21]. In the present study, it was confirmed that in lung-lavaged rabbits optimal gas exchange can be 

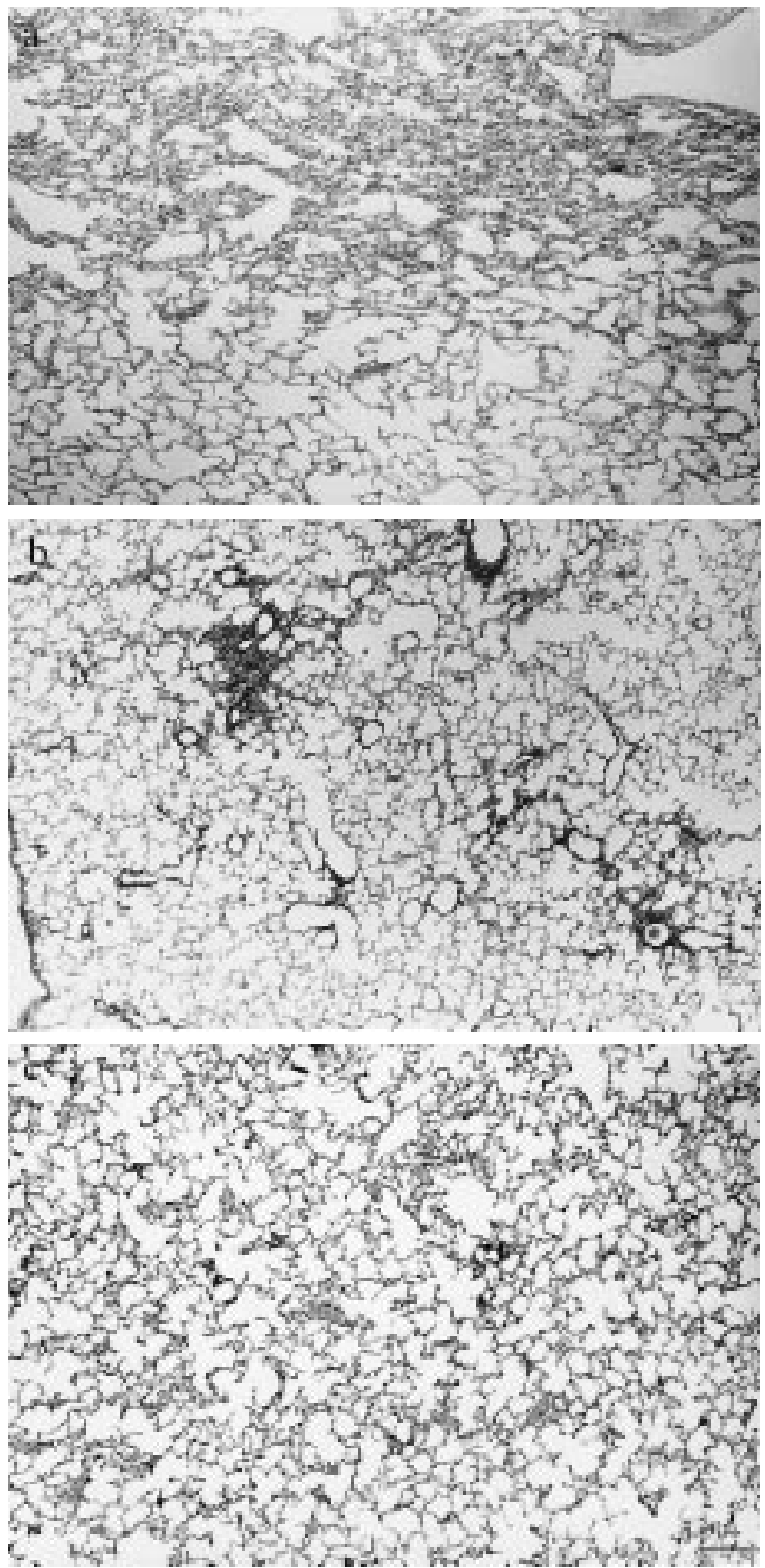

Fig. 3 - a) Half of the lung tissue is atelectatic in the group that were lavaged only. No cellular reaction exists and the septa are structured regularly. b) the lung tissue is evenly aerated and only focally atelectatic (group conventional mechanical ventilation+surfactant). Few granulocytes are situated next to bronchioli and small vessels. c) Aerated lung tissue with focal atelectasis (group high-frequency oscillatory ventilation+surfactant). Collapse of the alveoli is accompanied by a slight interstitial and intra-alveolar infiltrate. Light microscopy, haematoxylin eosin stain, internal scale bar $=500 \mu \mathrm{m}$.

obtained with HFOV without surfactant, by using the high-lung volume strategy. However, lung function does not improve over time, as shown by the results that mean $P \mathrm{a}, \mathrm{O}_{2}$ values at the end of the observation period were comparable with the post-lavage values at the same ventilatory support (fig. 1). This indicates that the reduced end-expiratory stability, due to the repeated lung lavages (i.e. surfactant deficiency), was apparently not improved
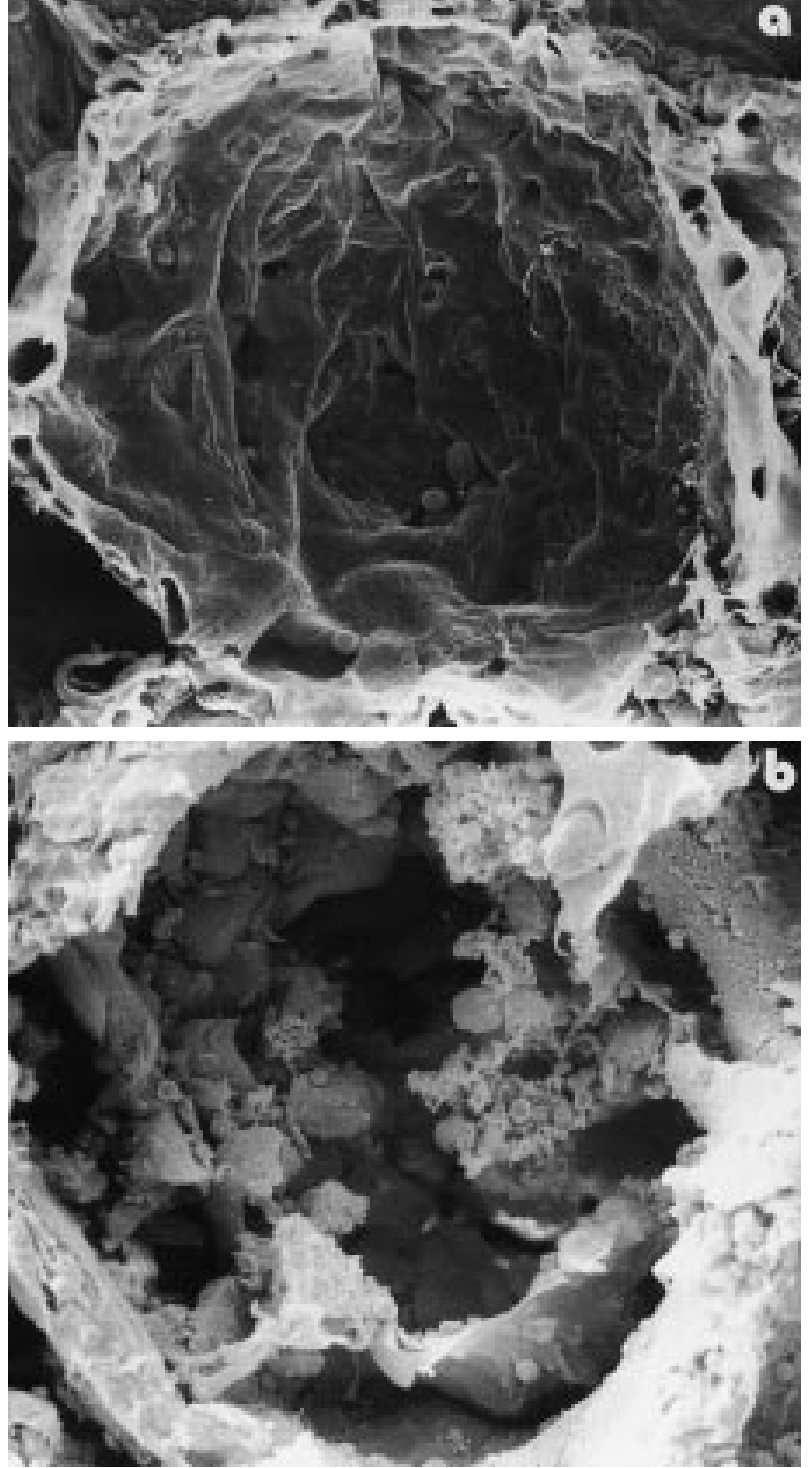

Fig. 4 -Representative alveoli of the group that received a) conventional mechanical ventilation for only $10 \mathrm{~min}$ after the lavage procedure and of the group that received b) high-frequency oscillatory ventilation (HFOV) without surfactant for $4.5 \mathrm{~h}$. The alveolus of the HFOV group contain fibrin, leukocytes, erythrocytes, and macrophages. Scanning electron microscopy, internal scale bar $=30 \mu \mathrm{m}$.

by HFOV. This confirms the results by MEREDITH et al. [22], who showed excellent gas exchange using HFOV with the high-lung volume strategy in premature baboons, but no beneficial effect on lung volume at zero pressure (functional residual capacity) determined at $24 \mathrm{~h}$. This indicates that optimization of alveolar expansion with HFOV markedly improves oxygenation but does not influence alveolar stability as long as the underlying cause, i.e. surfactant deficiency, is not reversed. This will occur by gradual synthesis of endogenous surfactant over time, or after exogenous surfactant instillation [15].

Morphological changes were more pronounced in the animals that received CMV or HFOV alone compared to the animals that were lavaged only (fig. 2). In surfactantdeficient lungs, high shear forces between open and 
closed alveoli are, to a great extent, held responsible for the damage caused by artificial ventilation [7]. Therefore, alveoli should be actively opened and kept open during the entire respiratory cycle in order to minimize additional lung damage $[2,3]$. Studies in lung-lavaged rabbits demonstrated that HFOV had beneficial effects on preventing the development of ventilator-induced lung injury when arterial oxygenation was kept above $46.7 \mathrm{kPa}(350 \mathrm{mmHg})$ (indicating alveolar expansion) and not when arterial oxygen tensions were maintained at $9.3-13.3 \mathrm{kPa}(70-100$ $\mathrm{mmHg})[2,3]$. This may explain the higher de-gree of lung injury seen in the present study in the group HFOV without surfactant. In that group, mean $\mathrm{Pa}_{\mathrm{a}} \mathrm{O}_{2}$ values dropped to $<13.3 \mathrm{kPa}(<100 \mathrm{mmHg})$ for only $30 \mathrm{~min}$, after MAwP was decreased to $\leq 9 \mathrm{cmH}_{2} \mathrm{O}$ at the end of the observation period (fig. 1). In contrast, mean $\mathrm{Pa}_{\mathrm{a}} \mathrm{O}_{2}$ values remained $>46.7 \mathrm{kPa}(>350 \mathrm{mmHg})$ almost for the entire observation period, despite the reduction of the MAwP, in both surfactant-treated groups (HFOV and CMV). Also, histopathological examinations of both groups that received surfactant (HFOV and CMV) showed no additional structural lung damage in comparison with the animals that were lavaged only (fig. 2). This result is supported by earlier experimental studies in which surfactant therapy has shown to improve uniform alveolar expansion and endexpiratory alveolar stability and thereby effectively prevents the progression of ventilator-induced lung injury [7, 23]. In the CMV group without surfactant, mean $\mathrm{Pa}_{\mathrm{a}} \mathrm{O}_{2}$ values were $<13.3 \mathrm{kPa}(<100 \mathrm{mmHg})$ during the entire study period and evidenced the highest lung injury score in this study (fig. 2). In contrast to HFOV, the CMV group did not receive a high-lung volume strategy. In pilot studies, McCulloch et al. [3] and Kolton et al. [24] tried to have a CMV group at high-lung volume but found that this was not possible. They concluded that the severity of lung lavage lesion necessitated such high ventilator pressures with CMV that fatal barotrauma terminated all such attempts [2].

In contrast to JACKSON et al. [9], the current study found no difference in the prevention of lung damage between HFOV and CMV after surfactant therapy (fig. 2). Further, it was shown that the HFOV group without surfactant showed more cellular infiltration and epithelial damage than the HFOV group with surfactant (fig. 2). This indicates that achieving and maintaining alveolar expansion (i.e. open lung) is of more importance than the type of mechanical ventilation (HFOV versus CMV). The importance of an open lung strategy is supported by the results of АмATO et al. [25] who recently demonstrated in adults with acute respiratory distress syndrome that CMV with an open-lung approach had, for the first time, a significant impact on survival and barotrauma. Therefore, it was concluded that surfactant therapy with CMV is equally effective to prevent ventilator-induced lung injury as HFOV combined with surfactant, as long as alveoli are opened and kept open to avoid high shear stress. This can be achieved by the use of a PEEP level that sufficiently counterbalances the retractive forces or by higher and/or repeated doses of exogenous surfactant to reduce the retractive forces.

It is concluded that after surfactant therapy the use of high-frequency oscillatory ventilation was not superior to conventional mechanical ventilation in improving gas exchange, lung deflation stability and reducing lung injury, if lungs are kept expanded independently of the mode of ventilation. Furthermore, it was confirmed that high-frequency oscillatory ventilation with the high-lung volume strategy markedly improves blood gases but without improvement of lung function, in particular arterial oxygenation at low mean airway pressure, in surfactant-depleted rabbits. This indicates that the high mean airway pressure used with high-frequency oscillatory ventilation only counterbalances the increased collapse tendency due to surfactant deficiency and therefore exogenous surfactant therapy is still required.

\footnotetext{
Acknowledgements. The authors thank E. Hendrik for expert technical assistance and L. Visser-Isles for English language editing.
}

\section{References}

1. HIFI study group. High-frequency oscillatory ventilation compared with conventional mechanical ventilation in the treatment of respiratory failure in preterm infants. $N$ Engl $J$ Med 1989; 320: 88-93.

2. Hamilton PP, Onayemi A, Smyth JA, et al. Comparison of conventional mechanical and high-frequency ventilation: oxygenation and lung pathology. J Appl Physiol 1983; 55: 131-138.

3. McCulloch PR, Forkert PG, Froese AB. Lung volume maintenance prevents lung injury during high frequency oscillatory ventilation in surfactant-deficient rabbits. Am Rev Respir Dis 1988; 137: 1185-1192.

4. Ogawa Y, Miyasaka K, Kawano T, et al. A multicenter randomized trial of high frequency oscillatory ventilation as compared with conventional mechanical ventilation in preterm infants with respiratory failure. Early Human Development 1992; 32: 1-10.

5. Clark RH, Yoder BA, Sell MS. Prospective, randomized comparison of high-frequency oscillation and conventional ventilation in candidates for extracorporeal membrane oxygenation. J Pediatr 1994; 124: 447-454.

6. Gerstmann DR, Minton SD, Stoddard RA, et al. The provo multicenter early high frequency oscillatory ventilation trial: improved pulmonary and clinical outcome in respiratory distress syndrome. Pediatrics 1996; 98: 10441057.

7. Nilsson R, Berggren P, Curstedt T, et al. Surfactant and ventilation by high frequency oscillation in premature newborn rabbits: effect on survival, lung aeration, and bronchiolar epithelial lesions. Pediatr Res 1985; 19: 143147.

8. Froese AB, McCulloch PR, Sugiura M, et al. Optimizing alveolar expansion prolongs the effectiveness of exogenous surfactant therapy in the adult rabbit. Am Rev Respir Dis 1993; 148: 569-577.

9. Jackson JC, Truog WE, Standaert TA, et al. Reduction in lung injury after combined surfactant and high-frequency ventilation. Am J Respir Crit Care Med 1994; 150: 534539.

10. Kobayashi T, Kataoka H, Ueda $\mathrm{T}$, et al. Effects of surfactant supplement and end-expiratory pressure in lung-lavaged rabbits. J Appl Physiol 1984; 57: 995-1001.

11. Gommers D, Vilstrup C, Bos JAH, et al. Exogenous surfactant therapy increases static lung compliance, and 
cannot be assessed by measurements of dynamic compliance alone. Crit Care Med 1993; 21: 567-574.

12. Segerer H, van Gelder W, Angenent FWM, et al. Pulmonary distribution and efficacy of exogenous surfactant in lung-lavaged rabbits are influenced by the instillation technique. Pediatr Res 1993; 34: 490-494.

13. Anonymous. Wet op de dierproeven. Staatsblad 1996; p. 500.

14. Lachmann B, Robertson B, Vogel J. In vivo lung lavage as an experimental model of respiratory distress syndrome. Acta Anaesthesiol Scand 1980; 24: 231-236.

15. Jobe AH. Pulmonary surfactant therapy. $N$ Engl $J$ Med 1993; 328: 861-868.

16. Suzuki H, Papazoglou K, Bryan AC. Relationship be-tween $P a, O_{2}$ and lung volume during high frequency oscillatory ventilation. Acta Paediatr Jpn 1992; 34: 494-500.

17. Veldhuizen RAW, Marcou J, Yao L-J, et al. Alveolar surfactant aggregate conversion in ventilated normal and injured lungs. Am J Physiol 1996; 270: L152-L158.

18. Verbrugge SJC, Böhm SH, Gommers D, et al. Surfactant impairment after mechanical ventilation with large alveolar surface area changes and effects of positive endexpiratory pressure. Br J Anaesth 1998; 80: 360-364.

19. Houmes RJ, Bos JAH, Lachmann B. Effects of different ventilator settings on lung mechanics: with special refer- ence to the surfactant system. Appl Cardiopulm Pathophysiol 1994; 5: 117-127.

20. Froese AB, Hill PE, Bond DM, Moller F. Maintaining alveolar expansion facilitates surfactant repletion in ventilated atelectasis-prone rabbits. FASEB $J$ 1988; 2: A1183.

21. Mannino FL, McEvoy RD, Hallmann M. Surfactant turnover in high frequency oscillatory ventilation. Pediatr Res 1982; 16: 356.

22. Meredith KS, DeLemos RA, Coalson JJ, et al. Role of lung injury in the pathogenesis of hyaline membrane disease in premature baboons. J Appl Physiol 1989; 66: 2150-2158.

23. Maeta H, Raju TNK, Vidyasagar D, et al. Effect of exogenous surfactant on the development of bronchopulmonary dysplasia in a baboon hyaline membrane disease model. Crit Care Med 1990; 18: 403-409.

24. Kolton M, Cattran CB, Kent G, et al. Oxygenation during high-frequency ventilation compared with conventional mechanical ventilation in two models of lung injury. Anest Analg 1982; 61: 323-332.

25. Amato MB, Barbas CSV, Medeiros DM, et al. Effect of a protective-ventilation strategy on mortality in the acute respiratory distress syndrome. $N$ Engl J Med 1998; 338: $347-354$. 